\title{
Design of Interesting Learning Modules with the STEM Approach on Dynamic Electrical Materials
}

\author{
Nursanti Situmorang ${ }^{1, *}$ Juniastel Rajagukguk ${ }^{2}$ Makmur Sirait $^{2}$ \\ ${ }^{1}$ Physics Education Study Program, Postgraduate School, of Universitas Negeri Medan, Indonesia 20221 \\ ${ }^{2}$ Department of Physics, Faculty of Mathematics and Natural Sciences, Universitas Negeri Medan, Indonesia 20221 \\ *Corresponding author. E-mail: nursantisitumorang19782312@gmail.com
}

\begin{abstract}
Dynamic electricity learning module based on STEM approach (Science, technology, engineering and mathematics) has been designed and developed. The cover and content of the module are designed as attractive as possible to make it easier for teachers to direct students in learning physics. In addition, through this module, students are expected to be able to improve higher-order thinking skills related to dynamic electricity. Assessment of the module is carried out to find out whether the module is feasible and practical to use. There are five aspects to measure the module including aspects of content feasibility, presentation, language, STEM elements, and graphic feasibility. Based on the results of the assessment by the media and learning materials, it was found that the module was very feasible (strongly agreed) to be used in dynamic electricity learning in schools.
\end{abstract}

Keywords: Module, STEM, feasibility aspect.

\section{INTRODUCTION}

One approach in learning Physics related to dynamic electricity is through the STEM approach. STEM stands for an interdisciplinary learning approach between Science, Technology, Engineering and Mathematics. Force, ST (2014) and Connor et al. 2013 states that the approach of these four aspects is a harmonious match between problems that occur in the real world and also problem-based learning [1-2]. The application of STEM in learning activities consists of 4Cs, namely creativity, critical thinking, collaboration, and communication, so that students can find innovative solutions to real problems faced and can convey them well [3-5]. The use of the STEM approach is intended so that students can have the ability and understanding in the four interrelated aspects of STEM on one subject, and can help students solve problems and draw conclusions from previous learning by applying them through science, technology, engineering and mathematics [6].

STEM-based learning is a combination of ideas and concepts of science with other disciplines, including the practice of science. Emphasizing the ability to solve theoretical and computational problems without presenting real problems is a serious challenge in today's world of education. This has implications for the low achievement grades in science students in Indonesia [7-
8]. Especially with the fact that the education community is being faced with the industrial revolution 4.0. Educational theorists judge that it is time and the educational process should be created in a new way. Massive changes in times require the world of education (including educators, students, education boards and others) to update and upgrade the way of education [9]. Skills in elaborating information, knowledge and technology are needed in order to carry out a capable classroom learning process in the classroom. Therefore the development of STEM-based learning is very important.

Based on the observations results in the State Senior High School 1 LUMBANJULU (SMA Negeri 1 Lumbanjulu) found that there are still many students who are not interested in Physics subjects. Even previous researchers have proven this, for example Lou, et al (2011) who found 12 facts about students' disinterest in Physics subjects [10]. Sutarto, et al (2014) who identified the influence of Physics learning media on students' interest in learning [11]. In addition to the above, according to the results of interviews with Physics teachers at SMA N 1 Lumbanjulu, the learning materials at the school are still inadequate or not available. They only use Physics books and worksheets that are already on the market. Even the teaching materials used are less attractive and the physics laboratory tools are limited. 
Especially during the Covid-19 pandemic which is hitting all walks of life, especially in the field of education. This situation resulted in the learning system that was originally face-to-face now changed to an online learning system (in the network). To continue to exist in the implementation of learning, teachers must ensure that learning activities must continue, even though students are at home. Teachers are required to be able to design learning media as innovations by utilizing online or online media. SMA Negeri 1 Lumbanjulu does Hybrid learning, which is twice a week they face to face besides that they study online, because the Lumbanjulu area is still a Green Zone in terms of the spread of Covid-19. But in this case there are many obstacles that hinder education. Usually this obstacle is inseparable from the location of the school and also the facilities available at the school. One of them is SMA Negeri 1 Lumbanjulu, a school in the countryside which is a little difficult to get an internet signal even though its position is right on the protocol road. This school has been around for a long time, but it has only been two years since implementing the 2013 Curriculum, to be precise, starting the 2018/2019 academic year. So the 2013 curriculum is still new, both for students, for teachers and for the school itself. However, the students who attend this school, especially class XII science, are students who have begun to understand the pattern or way of learning according to the demands of the curriculum, because they have been using the 2013 curriculum since class X. So the school continues to provide ways of learning. that must be understood by students and can meet the needs of students.

In this case, the STEM-based module is a solution for students so that they can learn independently and can build their own understanding of the concept of dynamic electricity by carrying out the activities in the module and being able to apply it in everyday life. Previous researchers have researched the development of STEMbased teaching materials including Afiffah et al. (2019) which states that STEM-based teaching materials are included in the appropriate category for use and can increase students' mastery of concepts which is marked by an increase in pre-test to post-test scores [12]. Jayani (2012) has researched on the The development of research-based learning model with science, environment, technology, and society approaches to improve critical thinking of students [13]. It was found that by using teaching materials in the form of modules, students are easier to follow Physics learning so that the learning process can take place effectively. The effectiveness of the module can be seen in the learning outcomes of $93.3 \%$ students who scored 70. This STEMbased module was developed using a research and development model that refers to the ADDIE (Analysis, Design, Development, Implementation and Evaluation) model [14]. This model is a systematic and coherent learning model design. The virtual lab STEM approach method with computer simulation can be implemented at SMA N 1 Lumbanjulu because the school has enough computer laboratories for each student. Advances in information technology can support the progress of learning Physics.

\section{METHOD}

This research was conducted at the State Senior High School (SMA) 1 Lumbanjulu, Toba Regency. The Physics learning module is designed through a STEM (Science, Technology, Engineering and Mathematics) approach by adapting the ADDIE development model (Analysis, Design, Development, Implementation, Evaluation. In the analysis stage, the initial state of students in terms of learning outcomes and initial abilities are presented. on the teacher's side and the availability of teaching materials such as modules and learning devices, an initial investigation is carried out. The next stage is the design of an attractive module that is in accordance with the STEM concept for electrical and dynamic materials in class XI high school students. The designed modules are given to material experts and media experts to an assessment is carried out. The assessment carried out on the module is to determine the feasibility aspects of the content, presentation, language and structure of the STEM content. This validation stage by experts has an impact on the complete improvement of the module. Therefore, improvements and developments are carried out according to suggestions from the validator team. After validated by experts i material and media content, then the appropriate module is obtained to be used by teachers in the implementation of learning for students. The instrument for assessing the feasibility of the module is carried out by using a Likert scale with 1 to 5 points [15].

\section{RESULT AND DISCUSSION}

\subsection{Modul Description}

The display of the module that contains elements of an attractive presentation with the STEM approach can be seen in Figure 1. The module that has been designed is filled with interesting pictures and is in accordance with the grade level and students' reasoning. In addition, interesting and varied color combinations are also presented in the module. 


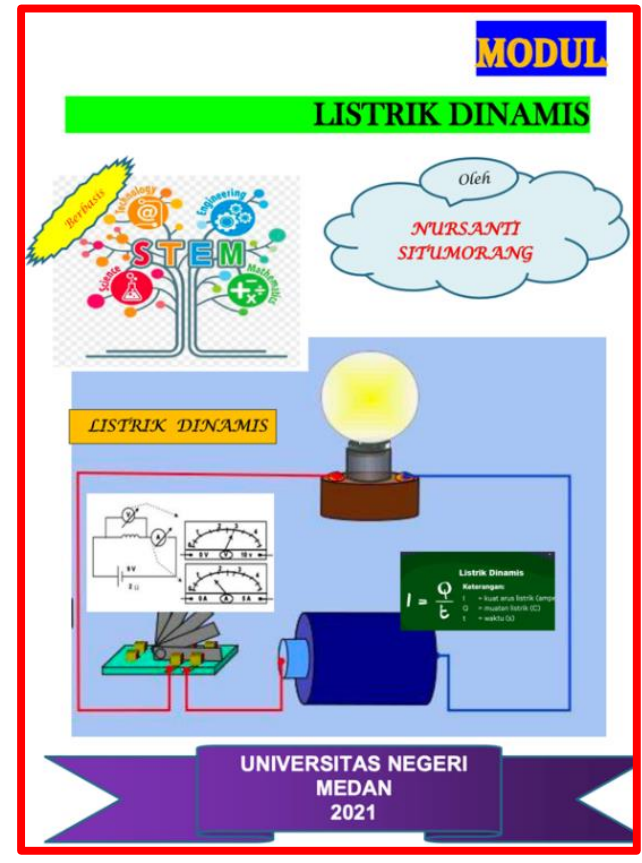

Figure 1. The interesting module cover view for electrical dynamic materials

In general, the initial information presented in the module starts from the competency standards to be achieved by students, basic competencies, indicators and objectives. Furthermore, elements of science were introduced at the beginning of the explanation of the learning material. To achieve student understanding, the definition of electric current is introduced through the concept of electrons and electric charge accompanied by a diagram of the charge. After the concept of electric current is delivered in the module, the next step is to give sample questions that aim to measure students' critical thinking skills. Elements of Technology are introduced after students understand the basic concepts of electric current. As shown in Figure 2, the use of technology in the management of electric current through image illustrations is displayed in the module. Simple questions that arouse students' reasoning abilities are also presented at this stage [16].

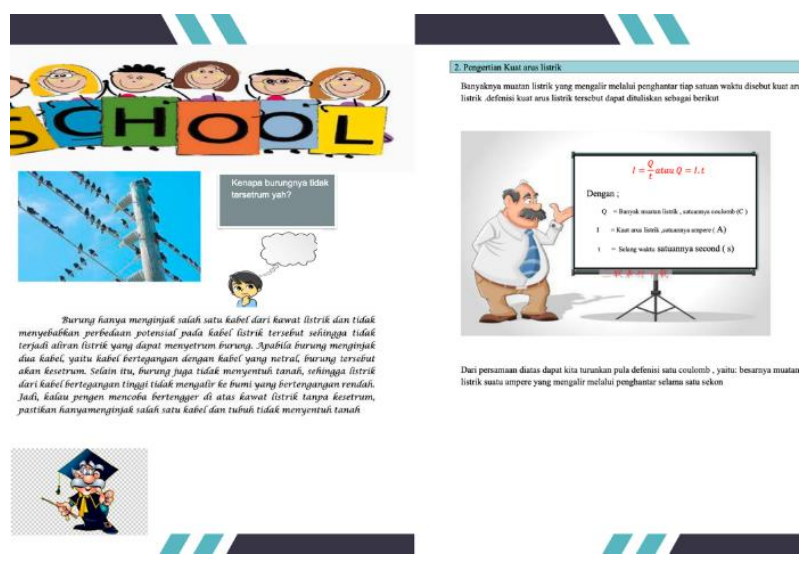

Figure 2. Module content with combining the STEM concept
After the STEM-based dynamic electricity learning module is obtained, the next step is to conduct a feasibility test. Several aspects that were tested to determine the feasibility of the module were aspects of the feasibility of content, presentation, language, content of STEM elements and graphics.

\subsection{The content Feasibility Aspect}

Some of the indicators used to measure the feasibility of the content are the suitability of the material with competency standards (SK) and basic competencies (KD), material accuracy, supporting learning materials, and up-to-date materials. Table 1 shows the acquisition score for each indicator, each of which is described in the form of a description. Each description is given a score by a learning content expert by following a Likert scale, namely 5 = Strongly Agree (SA); $4=$ Agree (A); $3=$ Neutral (N); 2 = Disagree (D); and 1 = Strongly Disagree (SD). As shown in Table 1, the average score for each indicator starting from the suitability of the material with the SK and KD to the latest material is $4.67 ; 4.37$; 4.83; and 4.5.

\subsection{Presentation Feasibility Aspect}

There are four indicators to measure the feasibility of the presentation aspect, namely presentation technique, presentation support, learning presentation, and presentation completeness. As shown in Table 2, it is known that the average score of each indicator is 4.5 ; $4.625 ; 5.0$; and 4.0 with the majority getting the predicate strongly agree. The description related to student involvement scored 5 (strongly agree) because the designed module is believed to be very interactive and easy for students to understand. However, on the indicator of completeness of presentation for the introduction, content and completion, the average score is 4 (agree), so it needs to be improved in further improvement.

\subsection{Feasibility Aspect of Language}

The measurement of the language aspect used in STEM-based dynamic electrical modules is one of the most important aspects to measure. Table 3 shows indicators, descriptions, scores and module measurement results based on language aspects. Based on the table, an average score of $4.3,4.5,4.5,4.5,5$, and 5 was obtained for each indicator of straightforward, communicative, dialogical and interactive, conformity with students, coherence and integration of the flow of thought and use of terms, symbols or icon. There are two indicators that predicate strongly agree, namely the coherence and coherence of the flow of thought and the use of terms, symbols or icons. This shows that the STEM-based module has compiled learning materials according to the order of students' abilities [17]. 
Table 1. The content feasibility aspect of electricity dynamic module

\begin{tabular}{|c|c|c|c|}
\hline Indicator & Descriptions & Score & Result \\
\hline \multirow{3}{*}{$\begin{array}{l}\text { A. Conformity of } \\
\text { material with SK and } \\
\text { KD }\end{array}$} & Material equipment & 5 & Strongly Agree \\
\hline & Material breadth & 4 & Agree \\
\hline & Material depth & 5 & Strongly Agree \\
\hline \multirow[t]{8}{*}{ B. Material Accuracy } & Concept accuracy and definition & 4 & Agree \\
\hline & Principle accuracy & 5 & Strongly Agree \\
\hline & Accuracy of facts and data & 4 & Agree \\
\hline & Sample accuracy & 4 & Agree \\
\hline & Question accuracy & 5 & Strongly Agree \\
\hline & Accuracy of drawings, diagrams and illustrations & 4 & Agree \\
\hline & Accuracy of notation, symbols and icons & 5 & Strongly Agree \\
\hline & Reference accuracy & 4 & Agree \\
\hline \multirow{6}{*}{$\begin{array}{l}\text { C. Supporting Learning } \\
\text { Materials }\end{array}$} & Reasoning (reasoning) & 4 & Agree \\
\hline & Linkages & 5 & Strongly Agree \\
\hline & Communication (Write and talk) & 5 & Strongly Agree \\
\hline & Application & 5 & Strongly Agree \\
\hline & Material attraction & 5 & Strongly Agree \\
\hline & Encouraging to seek further information & 5 & Strongly Agree \\
\hline \multirow[t]{4}{*}{ D. Material Update } & $\begin{array}{l}\text { The suitability of the material with the } \\
\text { development of science }\end{array}$ & 5 & Strongly Agree \\
\hline & Actual drawings, diagrams and illustrations & 5 & Strongly Agree \\
\hline & $\begin{array}{l}\text { Using case examples inside and outside } \\
\text { Indonesia }\end{array}$ & 4 & Agree \\
\hline & Library updates & 4 & Agree \\
\hline
\end{tabular}

Table 2. The Presentation Feasibility Aspect of STEM-based dynamic electricity learning module

\begin{tabular}{|l|l|c|c|}
\hline Indicator & Descriptions & Score & Result \\
\hline \multirow{3}{*}{$\begin{array}{l}\text { A. Presentation } \\
\text { Techniques }\end{array}$} & $\begin{array}{l}\text { Systematic consistency of presentation in } \\
\text { learning activities }\end{array}$ & 4 & Agree \\
\cline { 2 - 3 } & Clutter of presentation. & 5 & Strongly Agree \\
\hline \multirow{5}{*}{ B. Presentation support } & Examples of questions in each learning activity & 5 & Strongly Agree \\
\cline { 2 - 4 } & $\begin{array}{l}\text { Practice questions at the end of each learning } \\
\text { activity }\end{array}$ & 5 & Strongly Agree \\
\cline { 2 - 4 } & Answer key to practice questions & 5 & Strongly Agree \\
\cline { 2 - 4 } & Practice feedback. & 4 & Agree \\
\cline { 2 - 4 } & Introduction. & 4 & Agree \\
\cline { 2 - 4 } & Glossary. & 5 & Strongly Agree \\
\cline { 2 - 4 } & References. & 4 & Agree \\
\cline { 2 - 4 } & Summary & 5 & Strongly Agree \\
\hline \multirow{5}{*}{$\begin{array}{l}\text { C. Presentation of } \\
\text { Learning }\end{array}$} & Student involvement & 5 & Strongly Agree \\
\hline Dresentation & Introduction part & 4 & Agree \\
\cline { 2 - 4 } & Contents section & 4 & Agree \\
\cline { 2 - 4 } & Finishing Section & 4 & Agree \\
\hline
\end{tabular}


Table 3. Feasibility aspect for Language of of STEM-based dynamic electricity learning

\begin{tabular}{|l|l|c|c|}
\hline \multirow{2}{*}{ Indicator } & Descriptions & Score & Result \\
\hline \multirow{4}{*}{ A. Straightforward } & Correct sentence structure & $\mathbf{4}$ & Agree \\
\cline { 2 - 4 } & Sentence effectiveness. & $\mathbf{4}$ & Agree \\
\cline { 2 - 4 } & The standard of the term. & $\mathbf{5}$ & Strongly Agree \\
\hline \multirow{3}{*}{ C. Dialogic and interactive } & Message readability & $\mathbf{5}$ & Strongly Agree \\
\cline { 2 - 4 } & The accuracy of the use of language rules & $\mathbf{4}$ & Agree \\
\hline \multirow{2}{*}{$\begin{array}{l}\text { D. Conformity with the level } \\
\text { of development of students }\end{array}$} & $\begin{array}{l}\text { Ability to encourage critical thinking } \\
\text { development of students. }\end{array}$ & $\mathbf{4}$ & Agree \\
\cline { 2 - 4 } & $\begin{array}{l}\text { Conformity with the level of emotional } \\
\text { development of students }\end{array}$ & $\mathbf{5}$ & Strongly Agree \\
\hline \multirow{2}{*}{$\begin{array}{l}\text { E. Coherence and coherence } \\
\text { of the flow of thought }\end{array}$} & $\begin{array}{l}\text { Coherence and integration between } \\
\text { learning activities }\end{array}$ & $\mathbf{4}$ & Strongly Agree \\
\cline { 2 - 4 } & $\begin{array}{l}\text { Coherence and coherence between } \\
\text { paragraphs }\end{array}$ & $\mathbf{5}$ & Strongly Agree \\
\hline \multirow{2}{*}{$\begin{array}{l}\text { F. Use of terms, symbols or } \\
\text { icons }\end{array}$} & $\begin{array}{l}\text { Consistency in the use of terms and } \\
\text { symbols }\end{array}$ & $\mathbf{5}$ & Strongly Agree \\
\cline { 2 - 4 } & Consistency of using icons & $\mathbf{5}$ & Strongly Agree \\
\hline
\end{tabular}

Table 4. Assessment aspect of STEM of Electricity module

\begin{tabular}{|c|c|c|c|}
\hline Indicator & Descriptions & Score & Result \\
\hline \multirow[t]{5}{*}{$\begin{array}{l}\text { A. STEM } \\
\text { Characteristics }\end{array}$} & $\begin{array}{l}\text { This module integrates science, technology, } \\
\text { engineering and mathematics in one subject }\end{array}$ & 5 & $\begin{array}{l}\text { Strongly } \\
\text { Agree }\end{array}$ \\
\hline & $\begin{array}{l}\text { This module applies a project-based learning model } \\
(\mathrm{PjBL})\end{array}$ & 5 & $\begin{array}{l}\text { Strongly } \\
\text { Agree }\end{array}$ \\
\hline & $\begin{array}{l}\text { This module is in accordance with real life is } \\
\text { contextual }\end{array}$ & 4 & Agree \\
\hline & $\begin{array}{l}\text { This module prepares students with } 21 \text { st century life } \\
\text { skills }\end{array}$ & 4 & Agree \\
\hline & $\begin{array}{l}\text { This module trains students in learning the form of } \\
\text { soft skills and hard skills }\end{array}$ & 5 & $\begin{array}{l}\text { Strongly } \\
\text { Agree }\end{array}$ \\
\hline \multirow[t]{4}{*}{ B. STEM Principle } & $\begin{array}{l}\text { This module uses science knowledge and processes } \\
\text { in understanding physics concepts }\end{array}$ & 5 & $\begin{array}{l}\text { Strongly } \\
\text { Agree }\end{array}$ \\
\hline & $\begin{array}{l}\text { This module uses technology and how technology } \\
\text { can be used to facilitate human work }\end{array}$ & 4 & Agree \\
\hline & $\begin{array}{l}\text { This module trains students to be able to design, } \\
\text { apply and engineer a work in the form of creative } \\
\text { applications. }\end{array}$ & 5 & $\begin{array}{l}\text { Strongly } \\
\text { Agree }\end{array}$ \\
\hline & $\begin{array}{l}\text { This module trains students to be skilled in thinking } \\
\text { rationally and logically as well as reasoning and } \\
\text { using it mathematically and structured. }\end{array}$ & 4 & Agree \\
\hline
\end{tabular}




\subsection{Feasibility aspect of STEM}

The availability of STEM elements in the dynamic electricity learning module is something new and important to develop students' higher order thinking skills. Therefore, several indicators such as STEM characteristics and principles are embedded in the dynamic electrical module. The integration of science, technology, engineering and mathematics in a subject has been implemented in the module. This can be seen from the scores shown in Table 4 where the average score for STEM characteristics is 4.6 and for STEM principles is 4.5. Based on the results of measurements made by media experts, it is known that the module has utilized science knowledge and processes in understanding physics concepts.

\subsection{Feasibility aspect for Graph}

The measurement of the graph feasibility of the dynamic electricity learning module is the last aspect that must be observed. In this study there are 41 descriptions that are measured which are divided into three indicators. The average score is $4.50,4.57,4.45$ which relates to each indicator of size, cover design and module content design. Based on observations of the feasibility of graphics conducted by media experts, it was found that the size and layout of each display was proportional to the content of the module. In addition, the size and type of font used is also correct so that it is easy to read.

Table 5. Feasibility aspect for Graph of STEM-based dynamic electricity learning

\begin{tabular}{|l|c|c|}
\hline \multicolumn{1}{|c|}{ Indicator } & Score & Result \\
\hline A. Module Size & 4.50 & $\begin{array}{c}\text { Strongly } \\
\text { Agree }\end{array}$ \\
\hline $\begin{array}{l}\text { B. Module Cover Design } \\
\text { (Cover) }\end{array}$ & 4.57 & $\begin{array}{c}\text { Strongly } \\
\text { Agree }\end{array}$ \\
\hline C. Design Content Module & 4.45 & Agree \\
\hline
\end{tabular}

\section{CONCLUSION}

The dynamic electricity learning module based on the STEM approach (Science, technology, engineering and mathematics) for use in classroom learning has been designed and developed. The average module feasibility score is 4.6 (strongly agree); 4.5 (strongly agree); 4.6 (strongly agree); 4.5 (strongly agree); and 4.48 (agree) for each aspect of the feasibility of content, presentation, language, STEM elements, and graphic feasibility. Based on the feasibility and practicality analysis that has been done, it can be concluded that the dynamic electricity learning module through the STEM approach is very feasible to use in classroom learning.

\section{REFERENCES}

[1]. Force, S. T. (2014). Innovate: A blueprint for science, technology, engineering, and mathematics in California public education. Dublin, CA: Californians Dedicated to Education Foundation.

[2]. Connor, K. A., Ferri, B. H., \& Meehan, K. (2013, June). Models of mobile hands-on STEM education. In 2013 ASEE Annual Conference \& Exposition (pp. 23-910).

[3]. Lestari, I. (2018). Pengembangan bahan ajar matematika dengan memanfaatkan GeoGebra untuk meningkatkan pemahaman konsep. GAUSS: Jurnal Pendidikan Matematika, 1(1), 26-36.

[4]. Jonny, H. P., Rajagukguk, D., \& Rajagukguk, J. (2020). Computational Modelling Based on Modellus to Improve Students' Critical Thinking on Mechanical Energy. In Journal of Physics: Conference Series (Vol. 1428, No. 1, p. 012042). IOP Publishing.

[5]. Kartika, Y., Wahyuni, R., Sinaga, B., \& Rajagukguk, J. (2019, July). Improving Math Creative Thinking Ability by using Math Adventure Educational Game as an Interactive Media. In Journal of Physics: Conference Series (Vol. 1179, No. 1, p. 012078). IOP Publishing.

[6]. Bashooir, K., \& Supahar, S. (2018). Validitas dan reliabilitas instrumen asesmen kinerja literasi sains pelajaran fisika berbasis STEM. Jurnal penelitian dan evaluasi pendidikan, 22(2), 219-230.

[7]. Suardana, I. N., Redhana, I. W., Sudiatmika, A. A., \& Selamat, I. N. (2018). Students' Critical Thinking Skills in Chemistry Learning Using Local CultureBased 7E Learning Cycle Model. International Journal of Instruction, 11(2), 399-412.

[8]. Siregar, E., Rajagukguk, J., \& Sinulingga, K. (2020). Improvement of Science Process Skills Using Scientific Inquiry Models With Algodoo Media and Quotient Adversity in High School Students. Journal of Transformative Education and Educational Leadership, 1(2), 53-65.

[9]. Ulfah, M., Harahap, M. B., \& Rajagukguk, J. (2018, December). The Effect of Scientific Inquiry Learning Model for Student's Science Process Skill and Self Efficacy in The Static Fluid Subject. In 3rd Annual International Seminar on Transformative Education and Educational Leadership (AISTEEL 2018) (Vol. 2018). Atlantis Press.

[10].Lou, S. J., Shih, R. C., Diez, C. R., \& Tseng, K. H. (2011). The impact of problem-based learning strategies on STEM knowledge integration and attitudes: an exploratory study among female 
Taiwanese senior high school students. International Journal of Technology and Design Education, 21(2), 195-215.

[11].Sutarto,H.dkk. (2014). Metode Pemecahan Masalah menurut Polya untuk mengembangkan kemampuan siswa dalam pemecahan masalah Matematis disekolah Menengah pertama .EDU-Mat Jurnal Pendidikan Matematika ,2(1)

[12].Afifah, R., \& Ellianawati, E. (2019). Student Cognitive Profile with STEM Based Teaching Material on the Subject of Vibrations and Waves. Jurnal Penelitian \& Pengembangan Pendidikan Fisika, 5(2), 217-226.

[13].Usmeldi, U., Amini, R., \& Trisna, S. (2017). The development of research-based learning model with science, environment, technology, and society approaches to improve critical thinking of students. Jurnal Pendidikan IPA Indonesia, 6(2), 318-325.

[14].Alodwan, T., \& Almosa, M. (2018). The Effect of a Computer Program Based on Analysis, Design, Development, Implementation and Evaluation (ADDIE) in Improving Ninth Graders' Listening and Reading Comprehension Skills in English in Jordan. English Language Teaching, 11(4), 43-51.

[15].Nemoto, T., \& Beglar, D. (2014). Likert-scale questionnaires. In JALT 2013 conference proceedings (pp. 1-8).

[16].Schneider, M. R., \& Yarden, Y. (2016). The EGFRHER2 module: a stem cell approach to understanding a prime target and driver of solid tumors. Oncogene, 35(23), 2949-2960.

[17].Utomo, A. P., Hasanah, L., Hariyadi, S., \& Narulita, E. (2020). The Effectiveness of STEAM-Based Biotechnology Module Equipped with Flash Animation for Biology Learning in High School. International Journal of Instruction, 13(2), 463-476. 